\title{
OGÓLNOPOLSKA KONFERENCJA NAUKOWA „EKSPOZYCJE STAŁE W MUZEACH KOŚCIOŁA RZYMSKOKATOLICKIEGO. HISTORIA I WSPÓLCZESNOŚĆ", LUBLIN 15 GRUDNIA 2020 ROKU
}

Konferencja odbyła się w dniu 15 grudnia 2020 r. on-line z wykorzystaniem programu Teams, ze względu na przepisy epidemiczne. Organizatorami były Ośrodek Archiwów, Bibliotek i Muzeów Kościelnych KUL oraz Katedra Historii Kultury i Muzeologii UKSW. Uczestnikami sesji byli nie tylko prelegenci, ale i liczni słuchacze łączący się za pomocą Internetu.

Obrady otworzył dr hab. Tomasz Nowicki, prof. KUL, dyrektor Instytutu Historii KUL. W swoim wystąpieniu zwrócił uwagę na problematykę wystaw muzealnych, które w czasie zamkniętych placówek kultury są szczególnie istotne, aby móc korzystać z ekspozycji wirtualnie.

Pierwszym prelegentem był ks. bp dr hab. Mariusz Leszczyński, który przedstawił referat Muzeum Diecezjalne w Zamościu - historia, zbiory, ekspozycja. Wspomniana placówka jest jedną z młodszych diecezjalnych instytucji muzealnych, choć świętuje 25 lat swojego istnienia. Od początku jej dyrektorem jest ks. bp Mariusz Leszczyński. Placówka zgromadziła dotychczas ponad 1200 artefaktów, większość wycofanych z kultu i pochodzących głównie z kościołów parafialnych diecezji zamojsko-lubaczowskiej. Muzeum wydaje również nieregularnie periodyk „Biuletyn Muzeum Diecezjalnego w Zamościu” oraz okolicznościowe publikacje dotyczące swoich zbiorów. Dyrektor placówki bierze również udział w wielu konferencjach, sesjach i spotkaniach poświęconych muzealnictwu.

Ks. dr Tomasz Grabowski omówił zagadnienie Muzeum Diecezjalne w Łomży - sposoby ekspozycji. W swoim wystąpieniu dyrektor placówki przypomniał początki muzeum, otwartego w 2012 r. Jego siedziba powstała $\mathrm{w}$ ramach projektu

* Artur Hamryszczak - dr historii; adiunkt, Ośrodek Archiwów, Bibliotek i Muzeów Kościelnych, Katolicki Uniwersytet Lubelski Jana Pawła II w Lublinie

e-mail: artur.hamryszczak@kul.pl

https://orcid.org/0000-0002-2578-9971 
pn. „Renowacja zabytkowych obiektów kultury oraz rozbudowa Muzeum Diecezjalnego w ramach kompleksu Narew”. W budynku zgromadzono głównie obiekty wycofane z kultu z kościołów parafialnych. Są to zarówno obrazy i rzeźby, jak i paramenty liturgiczne. Artefakty są wystawione w tradycyjny sposób, w gablotach, odpowiednio zabezpieczone i oświetlone. W jednej z sal muzeum zrekonstruowano plebanię z wyposażeniem. Najnowszym osiągnięciem ekspozycyjnym jest możliwość zwiedzania muzeum diecezji łomżyńskiej on-line dzięki specjalnej aplikacji.

Dr Beata Skrzydlewska przedstawiła referat Wspótczesne aranżacje w muzeach kościelnych - projekty i realizacje. W swoim wystąpieniu przypomniała najważniejsze sposoby nowoczesnego eksponowania zbiorów muzealnych. Prace podczas tworzenia nowych muzeów i reorganizacji już działających szczególnie służyły unowocześnieniu ekspozycji, aby stała się ona bardziej atrakcyjna dla zwiedzających. Jako przykłady prelegentka podała Muzeum 200-lecia Diecezji Lubelskiej umiejscowione na poddaszu lubelskiego seminarium duchownego lub Muzeum Katedry Łowickiej, zorganizowane w wieży świątyni.

Ks. prof. Waldemar Żurek omówił Muzeum kardynała Augusta Hlonda w Czerwińsku nad Wisłą. W swoim wystąpieniu przybliżył sylwetkę hierarchy, który był jedną $\mathrm{z}$ najznamienitszych postaci polskiego Kościoła w okresie II Rzeczpospolitej i czasach powojennych. W latach 1926-1948 pełnił godność prymasa Polski. Jego działalność organizacyjna obejmowała zarówno kwestie kościelne (był pierwszym biskupem katowickim), polskiej emigracji (duszpasterz i założyciel Towarzystwa Chrystusowego nad Polonią Zagraniczną), jak i działalności wydawniczej (założył czasopismo „Gość Niedzielny”). Zgodnie z wolą kard. A. Hlonda jego spuścizna została po śmierci przekazana salezjanom w Lądzie, gdzie mieści m.in. nowicjat zgromadzenia, który ukończył hierarcha. Muzeum, które otwarto w 2015 r., zaaranżowano w pomieszczeniach klasztornych. Ekspozycja ma charakter tradycyjnej wystawy, z chronologicznym ułożeniem artefaktów, zgodnym z kolejnymi etapami życia ks. A. Hlonda (od narodzin na Śląsku, po śmierć w Warszawie). W salach wyeksponowano meble prymasa (m.in.biurko), rzeczy osobiste (np. portret) czy też paramenty liturgiczne używane przez hierarchę. Bardzo interesujące są albumy z rodzinnymi zdjęciami, spuścizna rękopiśmienna (kazania, notatki, listy itp.) oraz maska pośmiertna. W ekspozycji wykorzystano odpowiednio zaaranżowane światło, które podkreśla poszczególne elementy wystawy.

Dr Artur Hamryszczak przedstawił wiejskie, parafialne muzeum poświęcone Prymasowi Tysiąclecia w Zuzeli nad Bugiem (Tradycyjne sposoby ekspozycji w Muzeum Lat Dziecięcych Prymasa Tysiaclecia w Zuzeli). Placówka powstała w 1990 r. w celu upamiętnienia Stefana kard. Wyszyńskiego w miejscu, w którym się urodził w 1901 r. i chodził do szkoły. Muzeum mieści się w drewnianym budynku wikarówki z XIX wieku. We wnętrzu zrekonstruowano mieszkanie organisty Stanisława Wyszyńskiego, mieszkającego z rodziną w Zuzeli do 1910 r. Drugą część domu zaaranżowano na salę szkoły podstawowej, do której uczęszczał Stefan Wyszyński. Uznanie budzi bardzo drobiazgowe odtworzenie realiów zarówno mieszkania, jak i szkoły. Zwiedzający mają wrażenie, że ukazane pomieszczenia są 
nadal używane, a ich mieszkańcy na chwilę wyszli do swoich obowiązków. Ta tradycyjna ekspozycja bardzo silnie oddziałuje na zwiedzających, tym bardziej że realia otoczenia (kościół, zabudowania wsi) nadają rekonstrukcji wiarygodności.

Prof. Agnieszka Bender opowiedziała o Muzeum w Mentorelli jako przyktadzie ekspozycji zbiorów w kościelnych muzeach Italii. Wspomniana placówka znajduje się w sanktuarium Matki Bożej, jednym z najstarszych w Europie. Mentorella znajduje się ok. 60 km na wschód od Rzymu, na stoku góry Guadagnolo. Od 1857 r. sanktuarium opiekuje się Zgromadzenie Zmartwychwstania Pańskiego. Do miejsca tego często pielgrzymował Karol Wojtyła podczas swojego pobytu w Rzymie, również po wyborze na Stolicę Piotrową. Kościół pochodzi z XII wieku i jest wypełniony wieloma zabytkowymi przedmiotami. W klasztorze udostępniono do zwiedzania pokój, w którym zatrzymywał się Karol Wojtyła podczas swoich pobytów w sanktuarium. Elementem wystawienniczym jest też korytarz kościelny, w którym zgromadzono poszczególne artefakty. Należy pamiętać, że jest to miejsce kultu, stąd też kościół i klasztor można zwiedzać poza czasem nabożeństw.

Dr Anna Wiśnicka przedstawiła referat Minimalistyczne tendencje w aranżacji nowoczesnych wnętrz kościelnych. W swoim wystąpieniu skupiła się na nowych trendach w architekturze kościelnej. Nurt ten jest szczególnie silny w krajach Europy Zachodniej, gdzie nie tylko urządzane są tam w stylu minimalistycznym nowobudowane kościoły, ale również wiekowe świątynie. Ukazane przykłady aranżacji przestrzeni sakralnej budzą częstokroć skrajne emocje.

Ostatnim prelegentem był mgr Marcin Florek, który przedstawił Skarby Bożogrobców w Muzeum Ziemi Miechowskiej w Miechowie. Placówka powstała w 2012 r. jako wspólna inicjatywa samorządu lokalnego i parafii Grobu Bożego w Miechowie. Siedziba instytucji mieści się w budynkach poklasztornych przy bazylice bożogrobców. W swoich zbiorach gromadzi zabytki z dawnego Muzeum Regionalnego PTTK oraz ze skarbca bazyliki miechowskiej. W siedzibie muzeum zorganizowano dwie wystawy stałe, które odzwierciedlają dualizm zbiorów: Tkaniny i paramenty oraz Droga do wolności 1863-1918. Ekspozycje mają charakter tradycyjnego prezentowania artefaktów z wykorzystaniem nowoczesnych gablot i punktowego oświetlenia, które podkreśla walory estetyczne i historyczne obiektów. Wystawa tkanin i paramentów liturgicznych ze zbiorów bazyliki miechowskiej gromadzi najcenniejsze przedmioty w wyposażenia kościoła. Kolekcja tekstyliów skupia ponad 200 ornatów, kap i innych tekstyliów. Wystawę uzupełnia galeria opatów miechowskich oraz paramentów liturgicznych (monstrancje, puszki, ampułki itp.) ze skarbca bazyliki.

Po prezentacji referatów rozpoczęła się ożywiona dyskusja, podczas której uczestnicy dzielili się swoimi spostrzeżeniami i zadawali pytania prelegentom. Planowane jest wydanie referatów w formie artykułów naukowych.

Słowa kluczowe: muzeum kościelne; wystawa; aranżacja; artefakty; Kościół katolicki 


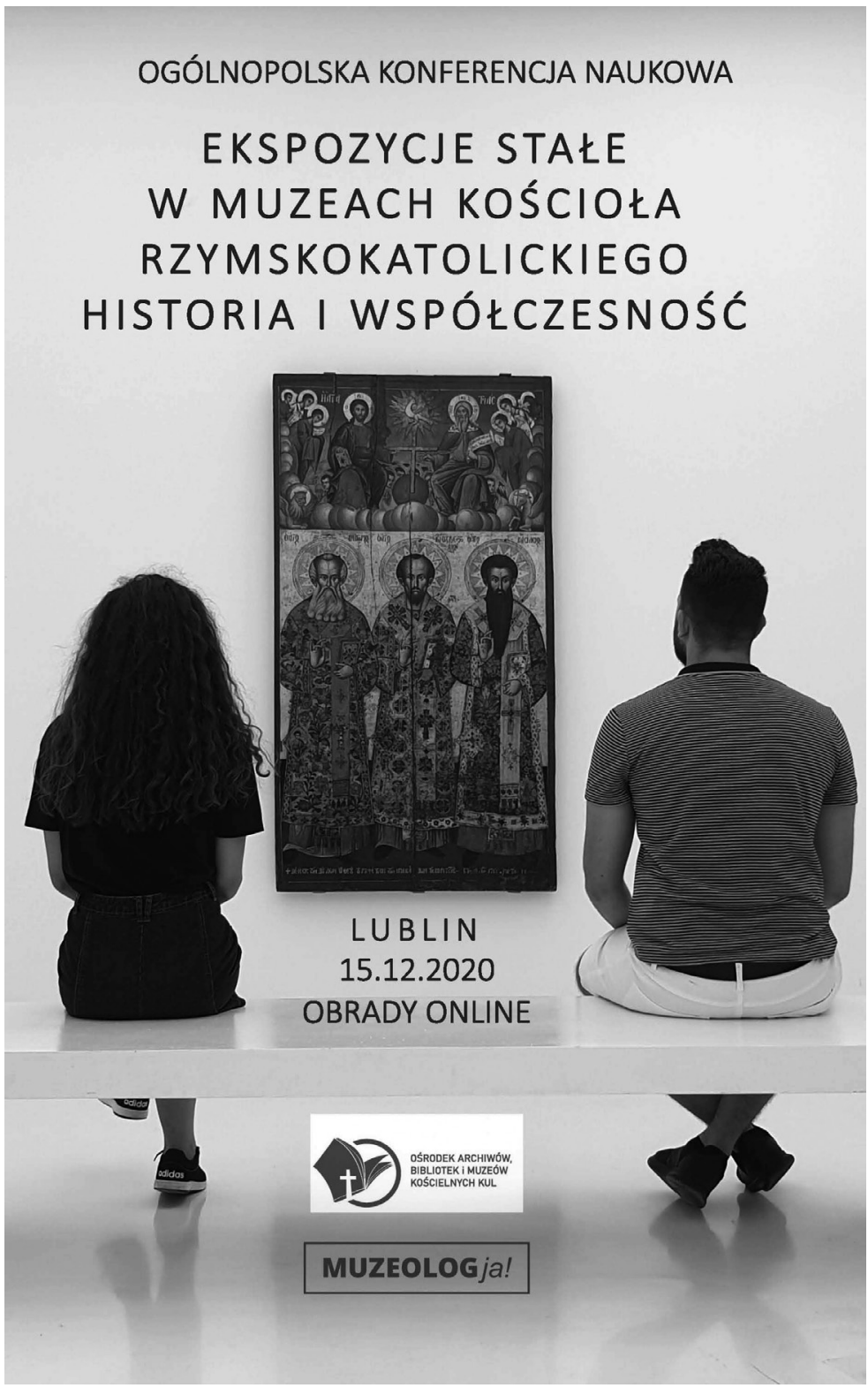

Il. 1. Plakat wykonała dr Anna Wiśnicka 